\title{
ARE EUPHEMISM AND DYSPHEMISM OPPOSITE ASPECTS OF ONE LINGUISTIC PHENOMENON?
}

\author{
Olga N. Prokhorova ${ }^{1}$ \\ Igor V. Chekulai ${ }^{2}$ \\ Elena V. Pupynina ${ }^{3}$ \\ Ekaterina F. Bekh ${ }^{4}$
}

\begin{abstract}
Euphemism and dysphemism are widely seen as opposite aspects of one linguistic phenomenon. However, there are facts of their use that raise questions about their status in relation to each other. This paper investigates functional side of dysphemism to define if it is opposite to euphemism. This research shows that functions that dysphemisms perform in text are similar to those fulfilled by euphemisms. However, there are details of their use such as their frequency, purpose, and intentions of the speaker that demonstrate that their opposition to each other is not absolute.
\end{abstract}

Key words: euphemism, dysphemism, semantics, pragmatics, stylistics.

\section{Introduction.}

There are many reasons to consider euphemisms and dysphemisms opposite aspects of one linguistic phenomenon. For instance, Merriam Webster's Dictionary defines them as opposite to each other.

"Euphemism - the substitution of an agreeable or inoffensive expression for one that may offend or suggest something unpleasant; also the expression so substituted" [1].

\footnotetext{
${ }^{1}$ National Research University "Belgorod State University" / "BelSU”, Russia, 308015, Belgorod, Studencheskaya Street, 17

${ }^{2}$ National Research University "Belgorod State University" / "BelSU”, Russia, 308015, Belgorod, Studencheskaya Street, 17

${ }^{3}$ National Research University "Belgorod State University" / "BelSU", Russia, 308015, Belgorod, Studencheskaya Street, 17

${ }^{4}$ National Research University "Belgorod State University" / "BelSU”, Russia, 308015, Belgorod, Studencheskaya Street, 17
} 


\section{Direite}

Periódico do Núcleo de Estudos e Pesquisas sobre Gênero e

Direito

Centro de Ciências Jurídicas - Universidade Federal da Paraíba

V. 8 - $\mathrm{N}^{\circ} 06$ - Ano 2019 - Special Edition

ISSN | 2179-7137 |

http://periodicos.ufpb.br/ojs2/index.php/ged/index

"Dysphemism - the substitution

of a disagreeable, offensive, or disparaging expression for an agreeable or inoffensive one; also an expression so substituted" [2].

However, some facts about the use of the two terms give grounds for wondering whether they are opposite to each other. The term "euphemism" was used as early as in 1681 whereas the first known use of the term "dysphemism" goes back to 1884. Look-up-popularity section of Merriam Webster's Dictionary site says that the term "euphemism" is in the top $10 \%$ of words whereas the term "dysphemism" is in the bottom $30 \%$ category [1], [2].

Linguistic literature review shows that the question about the status of euphemisms and dysphemisms in relation to each other remains unanswered. The goal of this article is to explore functions dysphemisms fulfill in text to see whether they are opposite to functions performed by euphemisms.

The interest of linguists to dysphemisms has grown recently, but attempts to define them have been made many times. Exploring dysphemisms linguist G. Hughes writes "Although this linguistic mode has been established for centuries and the term dysphemism was first recorded in 1884, it has only recently acquired even a specialist currency, being unlisted in many general dictionaries and reference books" [3, p. 142].

In 1969, O. S. Akhmanova proposed the following definition: "Dysphemism is a trope that implies substitution of a more vulgar, familiar or rude word for a neutral name of an object..." [4].

Allan K. and K. Burridge define dysphemism as a phrase having connotations that are offensive to hearers or negative connotations about the denotaum, or both, that is substitute for a neutral word or euphemism [5].

A word or a phrase can become dysphemistic when it conveys a feeling of disparagement. Using such words or phrases speakers can express their attitude to the state of affairs, their own opinion of what is happening. The word can be regarded a dysphemism when it is used to offend, insult or to express disrespect. Using dysphemism speakers frequently seek to articulate their views as well as to provoke a certain response 
Periódico do Núcleo de Estudos e Pesquisas sobre Gênero e

Direito

Centro de Ciências Jurídicas - Universidade Federal da Paraíba V. 8 - $\mathrm{N}^{\circ} 06$ - Ano 2019 - Special Edition

ISSN | 2179-7137 |

http://periodicos.ufpb.br/ojs2/index.php/ged/index

in hearers.

Dysphemistic or euphemistic effects can arise from deliberately distorted pronunciation of a word. V. I. Zhelvis writes about such effects providing the use of the word "bad" by African Americans as an example. If the word is pronounced [bæd], it conveys its traditional meaning "of low standard, unpleasant". If the speaker wants to demonstrate a supportive attitude, the pronunciation of the word is [ba:d]. Another example is the word "bastard", which is traditionally pronounced [ba:stə(r)d] and means "a child born out of wedlock". If the pronunciation of the word is changed to [bAstad], its meaning changes to rough and negative [6].

Attempts to define dysphemism were also made as part of studying euphemisms. Some linguists show that these concepts are overlapping, which makes it difficult to draw a line between them. Furthermore, they are so interconnected that in some cases studying one of them may be impossible without studying the other [7].

A. N. Morokhovsky et al. define dysphemisms as counterparts of euphemisms pointing out that dysphemisms are used as substitutes for stylistically neutral words and phrases to enable the speaker to express negative emotions such as irritation, hatred, anger [8].

Some researchers do not distinguish between euphemism and dysphemism as lexical units but as processes that lead to results in the form of lexical units. Gómez considers dysphemism and euphemism from this point of view highlighting two positive aspects in this approach. Firstly, it provides the definition of euphemism as belonging to speech rather than to language, which points to its discursive use and its pragmatic aspect integrated into speech linguistics. Secondly, it gives the opportunity to develop a complete classification of linguistic mechanisms involved in the functioning of euphemism including phonetic, morphological, syntactic, and other aspects. One of the limitations with this approach is that it still characterizes functions of euphemism on a lexical level interpreting it in terms of substitution [9].

In his further clarifications, Gómez notes that semantic 
Periódico do Núcleo de Estudos e Pesquisas sobre Gênero e

Direito

Centro de Ciências Jurídicas - Universidade Federal da Paraíba V. 8 - $\mathrm{N}^{\circ} 06$ - Ano 2019 - Special Edition

ISSN | 2179-7137 |

http://periodicos.ufpb.br/ojs2/index.php/ged/index

neutralization in euphemism functions as

a designative fact occurring in speech.

$\mathrm{He}$ also thinks that characteristics assigned to people and things by euphemism are based on the forbidden term rather than on the forbidden reality [9].

Having discussed what is meant by dysphemisms in linguistics, we will now move on to address euphemisms. The tradition of using euphemisms goes back to religious rituals that had taboos against using certain words that were believed to cause mischief as priests thought. Therefore such words were replaced by those promising a good omen [10].

Substitution of one word for another has evoked interest of language experts from ancient times. In Ancient period this linguistic phenomenon was discussed in the frameworks of rhetoric. Demetrius referred to it in his work "On Style" as early as in $1 \mathrm{AD}$ : "An element of vigour may also be found in what is called 'euphemism', whereby a man makes inauspicious things appear auspicious and impious acts appear pious. A speaker once urged that the golden Statues of Victory should be

melted down, so that the proceeds might be used to prosecute the war. But he did not say outright, 'Let us cut up the Victories for the war'. Such a proposal would have seemed impious and like an insult to the goddesses. He put it in the more euphemistic form: 'We will seek the cooperation of the Victories for the war'. This expression seems to suggest not the cutting up of the Victories, but the conversion of them into allies." [11, p. 195]. So, within the frameworks of classical rhetoric euphemisms were understood as instruments allowing greater expressiveness to preserve the harmony of speech and its relevance.

The Renaissance made euphemisms the object of studies in stylistics. For a long time researchers did not go beyond the bounds of language trying to explain mainly the connection between the meaning of euphemisms and the concepts they replaced. For instance, John Lyly in his book "Euphues, The Anatomy of wit" defines euphemism as stylistic device [12]. Stylistics still characterizes euphemisms as a way to soften expression of concept.

Euphemisms make up a significant linguistic layer since "a 
Periódico do Núcleo de Estudos e Pesquisas sobre Gênero e

Direito

Centro de Ciências Jurídicas - Universidade Federal da Paraíba V. 8 - $\mathrm{N}^{\circ} 06$ - Ano 2019 - Special Edition

ISSN | 2179-7137 |

http://periodicos.ufpb.br/ojs2/index.php/ged/index

language without euphemisms would be a defective communication tool" [13].

In the second half of the 20th century, euphemisms researchers begin to take extralinguistic factors into account. They conclude that the use of euphemisms is not limited by linguistic needs. Accordingly, the focus of research into this topic shifts to the area of sociolinguistics.

Researchers associate the occurrence of euphemisms in speech not only with linguistic, but also with social factors. In linguistic literature, two groups of euphemisms are identified. Euphemisms from the first group occur due to religious beliefs, fears and superstitions. They are used for names of gods, forces of nature, various diseases and topic of death. Euphemisms from the second group occur in the context of taboos, moral and social norms.

In addition, definitions of euphemisms and dysphemisms include psychological aspects.

Euphemisms are usually divided into positive and negative types [14]. Euphemisms are used positively in situations of common social mores and expressing solidarity with the addressee.
496

Euphemisms are used negatively to eliminate everything unpleasant and negative, eradicate from the language everything that people prefer not to deal with directly and may be afraid to talk of. It should also be noted that all euphemisms are used unconsciously or consciously [14]. Unconscious euphemisms usually do not have a clearly recognized origin. Conscious euphemism is applied purposefully; their meaning is clear and of imaginative character. This type of euphemism is frequently found in political discourse where it is sometimes important to avoid controversial issues. However, due to a more complex character, euphemism of the second type is dubious in nature, which may change its purpose from avoiding offense to deceiving [14]. Accordingly, one of the reasons for the use of euphemism lies in the area of political correctness that has become highly influential in recent years.

Cultural factors are also taken into account. For example, T. A. Artyushkina believes that "...the grounds for the euphemistic substitution are specific to each language and are due to the peculiarities of the culture and 
Periódico do Núcleo de Estudos e Pesquisas sobre Gênero e

Direito

Centro de Ciências Jurídicas - Universidade Federal da Paraíba V. 8 - $\mathrm{N}^{\circ} 06$ - Ano 2019 - Special Edition

ISSN | 2179-7137 |

http://periodicos.ufpb.br/ojs2/index.php/ged/index

society, historical and social changes, expressiveness making speech more that is, the whole non-linguistic life situation" [15].

The results of this investigation of linguistic literature suggest that occurrence of dysphemism and euphemism in speech is explained by complex factors.

\section{Method.}

The data for the study was gathered from works of modern British literature. The data contains extracts presenting speech of the characters where dysphemisms are found. This study examines functions of dysphemisms through context, semantic, and pragmatic analysis.

\section{Results and discussion.}

The study of dysphemisms reveals functions they perform in speech.

1. Dysphemisms are used to show emotional attitude (usually a negative one such as irritation, neglect, etc.) and value judgment in relation to the subject matter of the talk.

2. Dysphemisms provide vivid.

3. Dysphemisms are used as an attempt to manipulate opponents, shock or discredit them.

These uses can be illustrated by extracts from literature. In the first case, the speaker replaces a neutral word with a deflate style word to demonstrate his or her negative attitude towards the subject of the conversation. The emotional aspect is present in this group of dysphemisms.

"And hurry up, Tommy, if you don't want this lad to croak." Her words stabbed at Agnes like an ice pick. Yes; what if he croaked? What if he died? And she cried within herself. (C. Cookson. The Wingless Bird.) This example demonstrates that the use of the dysphemism "croak" instead of "die" helps the speaker to avoid direct reference to death and to express the negative attitude towards the concept of death.

"And if you want the bed camouflaged in the morning you can get up and make it. And I'm giving you this ultimatum: tomorrow night I come into this bed and if you try to stop me, you'll 
end up next door for the remainder of your days." Now her mother's voice, thin, piercing: "You try any trick like that on me, Arthur Conway, and you'll be sorry. Those two along the corridor will then know exactly what kind of a father they have, and about the slut you keep on the side under cover of the club nights." (C. Cookson. The Wingless Bird.) In this extract, the wife expresses an open negative attitude towards her husband's mistress using a rude word in relation to her.

"Finally he lay prone, still, exhausted; and bitter tears oozed out between his eyelids. He buckled under the final, inescapable realization that he had failed, and would always fail; that the jeering kids, the mocking men, the scornful tarts, were right; that he was nothing but a turd in the gutter. Frowning, Mark went into the kitchen for his customary cup of cocoa." (D. Lodge. The Picturegoers.) This extract shows the speaker's expression of the negative attitude to himself, his bitterness and dissatisfaction with himself.

Dysphemisms of the second group do not display negative attitude towards the subject matter of the talk or thought. The speaker uses them for of conveying expressive potential of the speech. In this case, dysphemism, in fact, is a figure of speech and it is used to embellish the utterance. This category of dysphemism can overlap with slang and argot since it is associated with certain social and age groups.

"Garfield smiles like an idiot. "He tries," Paul says. "He couldn't fucking handle it." Paul checks the chops. "OK. He couldn't handle Mum, he couldn't handle me," John says." (J. Neale. The Laughter of Heroes.) The character continues speaking about the topic using the dysphemism again to further strengthen his words: "He is going to find out eventually." Paul hates saying this, but it needs saying. "How's he going to feel then?" "Maybe he'll peg out first," John says. Now Paul turns from the cooking and looks directly into John's blue eyes. His friend looks stricken." (J. Neale. The Laughter of Heroes.)

"Lordy!" said the voice. "Left the slops an' all. She'll have to go. I ain't paying the slut for nothing. Just th'wait, my gal. There's a hiding for thee when 
Periódico do Núcleo de Estudos e Pesquisas sobre Gênero e

Direito

Centro de Ciências Jurídicas - Universidade Federal da Paraíba V. 8 - $\mathrm{N}^{\circ} 06$ - Ano 2019 - Special Edition

ISSN | 2179-7137 |

http://periodicos.ufpb.br/ojs2/index.php/ged/index

th'gets back from th'gallivanting!" (M. Darke. The First of Midnight.) In this extract, the word "slut", which we have already cited as an example of expressing a negative attitude to the subject matter, is used to emphasize the phrase as a means of expression.

"Get your hands off my daughter! And who the hell are you? But need I ask." He peered further. "My God in heaven! That she has let the likes of you touch her. You're a Felton, aren't you? One of the scum from the quay. Christ Almighty!" "I'm no more scum than you, mister. At least when I take a wife it'll satisfy me. I wouldn't go whoring. Look" - he stepped back, at the same time pushing Jessie to the side - "I don't want to knock you out, seein' as you're her father, but by God! I'll do it, if you come at me like that again." (C. Cookson. The Wingless Bird.) This example shows that the first participant in the dialogue displays his negative attitude to the second one. The other speaker repeats the word "scum" in his response targeting it at the first speaker. However, in this extract the role of the dysphemisms used is dubious. On the one hand, they add expressiveness to the speech making it more convincing. On the other hand, their purpose is to embarrass the opponent.

Dysphemisms of the third group are for manipulation purposes. Speakers use them to discredit the counterpart in communication, to knock the bottom out of him or her. Dysphemisms from this category are frequently found in political, advertising discourse. The purpose of discrediting the subject matter of the talk or the communication partner is combined with direct expression of negative attitude towards them.

"The flying hairdryer hit him just above the eye, flex trailing like the tail of a kite, and as he swatted it away the plug whipped around and smacked into his teeth. The fury burst again in his head like an overloaded artery, washing through him in a hot and irresistible wave. He was half-blinded as he reached for her. His hand shot out like a slaughterhouse bolt, and closed on air; she'd ducked out from under, and was already halfway to the door. "Cheap little slut," he yelled. "What would your father say?" (S. Gallagher. Rain.) This is the third extract with the word "slut". This 


\section{Direite}

Periódico do Núcleo de Estudos e Pesquisas sobre Gênero e

Direito

Centro de Ciências Jurídicas - Universidade Federal da Paraíba

V. 8 - $\mathrm{N}^{\circ} 06$ - Ano 2019 - Special Edition

ISSN | 2179-7137 |

http://periodicos.ufpb.br/ojs2/index.php/ged/index

500

example demonstrates that the speaker uses the word as direct insult.

"Turning violent red, he snatched it back and rubbed it clumsily against his trouser leg. Then he just brushed the very tips of his fingers against hers and plunged the offending hand deep in his pocket as if his fist were on fire and the pocket was a bucket full of sand. "And are these the children?" She turned to them with a glowing smile. It was like being bathed in honey. "Get up, you scum!" rapped Thacker with some of his old spirit. He was back on home ground, dealing with them "Oh, please, let them stay as they are. They must be tired after their labours." (P. Scobie A Twist of Fate.) The speaker tends to be rude towards the witness of the scene. This attitude is aimed at shocking the girl.

The results of this study show that a dysphemistic word or phrase may be used in different contexts for different purposes. It makes its lexical aspect less important highlighting pragmatic and sociocultural aspects.

\section{Conclusion.}


Periódico do Núcleo de Estudos e Pesquisas sobre Gênero e Direito Centro de Ciências Jurídicas - Universidade Federal da Paraíba V. 8 - $\mathrm{N}^{\circ} 06$ - Ano 2019 - Special Edition ISSN | 2179-7137 | http://periodicos.ufpb.br/ojs2/index.php/ged/index

In general, it seems that the reasons why euphemisms and dysphemisms are frequent in speech are rather similar. However, the details such as their frequency, purposes and intentions underlying their use, the number of functions they perform show that there are significant differences between them. Consequently, their opposition to each other is not absolute.

\section{Acknowledgments}

This work was supported by Belgorod State National Research University (research grant).

\section{References}

Euphemism. 2019. In MerriamWebster.com. Retrieved August 15, 2019 , from https://www.merriamwebster.com/dictionary/euphemism.

Dysphemism. 2019. In MerriamWebster.com. Retrieved August 15, 2019 , from https://www.merriamwebster.com/dictionary/dysphemism.

Hughes, G., 2006. An Encyclopedia of Swearing: The Social History of Oaths, Profanity, Foul Language, and Ethnic
Slurs in The English-Speaking World. Armonk: M. E. Sharpe.

Akhmanova, O. S., 1969. Slovar lingvisticheskih terminov. Moskva: Sovetskaya Entsiklopediya.

Allan, K. and K. Burridge, 1991. Euphemism and Dysphemism: Language Used as Shield and Weapon. New York: Oxford University Press.

Zhelvis, V. I., 1990. Emotivny aspect rechi: Psyholingvisticheskaya interpretatsiya rechevogo vozdeistviya. Yaroslavl: Yaroslavsky gosudarstvenny universitet.

Warren, B., 1992. What Euphemisms Tell us about the Interpretation of Words. Studia Linguistica, 46 (2): 128-172.

Morokhovsky, A. N., Vorobyova, O. P., Likhosherst, N. I. and

Z. V. Timoshenko, 1984. Stilistika angliyskogo yazyka. Kiev: Vyshcha shkola.

Gómez, M. C., 2012. The Expressive Creativity of Euphemism and 
Periódico do Núcleo de Estudos e Pesquisas sobre Gênero e

Direito

Centro de Ciências Jurídicas - Universidade Federal da Paraíba V. 8 - $\mathrm{N}^{\circ} 06$ - Ano 2019 - Special Edition ISSN | 2179-7137 | http://periodicos.ufpb.br/ojs2/index.php/ged/index

Dysphemism. Lexis. Journal in English Lexicology, 43-64. URL: URL : http://journals.openedition.org/lexis/349

Barinova, A. V., 2002. Stilisticheskaya oppositsiya evfemism / disfemism v kurse funktsionalnyh stiley sovremennogo russkogo literaturnogo yazyka. K postanovke problemy. Funktsionalnye stili. Zhanry. Idiolekty., 4(12): 44-48.

Demetrius, 1902. On Style. With introduction, translation, facsimiles, etc. by W. Rhys Roberts. Cambridge University Press.

Lyly, J., 2003. Euphues: The Anatomy of Wit and Euphues and his England. An annotated, modern-spelling edition. Ed. by Leah Scragg. Manchester and New York: Manchester University Press.

Enright, D. J., 1985. Fair of Speech: The Uses of Euphemism. Oxford: Oxford University Press.

Rawson, H., 1981. A Dictionary of Euphemisms and Other Doubletalk. Being Compilation of Linguistic Fig
Leaves and Verbal Flourishes for Artful Users of the English Language. New York: Crown Publishers, Inc.

Artyushkina, L. V., 2001. Semantichesky aspect evfemisticheskoy lexiki $\mathrm{v}$ sovremennom angliyskom yazyke. Moskva.

\section{Information about the authors}

Olga Nikolaevna Prokhorova, Doctor of Philology, Professor, National Research University "Belgorod State University" / "BelSU”, Russia, 308015, Belgorod, Studencheskaya Street, 17 prokhorova@,bsu.edu.ru, $\quad+7$ (4722) 245400 .

Igor Vladimirovich Chekulai, Doctor of Philology, Professor, National Research University "Belgorod State University" / "BelSU”, Russia, 308015, Belgorod, Studencheskaya Street, 17 chekulay@bsu.edu.ru, $\quad+7$ (4722) 301245.

Elena Vladimirovna Pupynina, $\mathrm{PhD}$ (Philology), Associate Professor, National Research University "Belgorod 
Periódico do Núcleo de Estudos e Pesquisas sobre Gênero e Direito Centro de Ciências Jurídicas - Universidade Federal da Paraíba V. 8 - No 06 - Ano 2019 - Special Edition ISSN | 2179-7137 | http://periodicos.ufpb.br/ojs2/index.php/ged/index

State University" / "BelSU", Russia,

308015, Belgorod, Studencheskaya

Street, 17

pupynina@bsu.edu.ru, +7

(4722) 301245.

Ekaterina Feodorovna Bekh,

Instructor, National Research University

"Belgorod State University" / "BelSU",

Russia, 308015, Belgorod,

Studencheskaya Street, 17

bekh@bsu.edu.ru, +7 (4722) 30

1245 